\title{
Relevancia de la necesidad de captar la atención en la publicidad
}

David López Jiménez

EAE Business School

\section{Referencia de este artículo}

López Jiménez, David (2021). Relevancia de la necesidad de captar la atención en la publicidad. En: adComunica. Revista Científica de Estrategias, Tendencias e Innovación en Comunicación, $\mathrm{n}^{0}$ 21, 295-298. DOI: http://dx.doi.org/10.6035/21740992.2021 .21 .15

Comerciantes de atención: la lucha épica por entrar en nuestra cabeza.

Wu, Tim (2020).

Madrid: Capitán Swing.

En la actualidad, vivimos en un mundo en el que la información es muy abundante, pero, además, está por todas los ámbitos por los que nos movemos. Cada vez resulta más frecuente y sencillo poder acceder a numerosos datos, artículos y recibir un importante volumen de impactos de contenido. Ahora bien, esto último, en más ocasiones de las deseables, supone cierto grado de agobio para los destinatarios, por lo que los consumidores pueden llegar a padecer lo que se denomina fatiga informativa $y$, de alguna manera, se ven superados por tantas ofertas. En otras palabras, impera tanta información que se sienten saturados de un tema, por lo que tienen el sentimiento de cierta sensación de frustración ante un exceso de contenidos que no pueden llegar a procesar. Asimismo, debe considerarse que cada vez hay más pantallas, y, además, en virtud de las mismas, se acceden a más fuentes de información. Todo ello, entre otros aspectos, ha supuesto que los consumidores accedan a más información y también que dejen a un lado aquella que estaban recibiendo.

Todo cuanto se plantea está teniendo un impacto muy significativo sobre las acciones que las marcas están realizando con el objetivo de llegar a los consumidores. El impacto que los smartphones están teniendo para que los consumidores detengan su atención en los anuncios que exhiben está siendo muy significativo. Por todo ello, podríamos plantearnos si realmente el teléfono móvil está acabando con la 
publicidad tradicional y, en concreto, aquella que se exhibe en el mundo exterior. Todo ello pone de relieve que para llegar a los consumidores las marcas tienen que acometer acciones más sorprendentes y esforzarse mucho más que en el pasado.

A todo cuanto, a modo de introducción, se ha apuntado, se refiere la obra que es objeto de reseña. En la misma se describe como numerosas empresas se dedican a tener nuestra atención, con el objetivo de obtener determinados datos y, posteriormente, tratarlos de manera informática. Se trata, en definitiva, de venderlos al mejor postor. Cuando nos ofrecen algo de manera gratuita, debemos interpretar que el producto somos nosotros mismos. El autor de la obra, Wu, detalla, de manera magistral, los orígenes de la invención de la publicidad en los Estados Unidos y su evolución para lograr la atracción de las masas. En este sentido, cabe referirse, a título de ejemplo, a los dos sugerentes supuestos: The New York Sun - primer periódico de un centavo con una importante cantidad de anuncios para financiarse- y los carteles de Jules Chéret en Francia. Chéret tuvo una carrera muy exitosa, que incluyó carteles de teatros, cabarets, así como de un larguísima listado de productos.

En la introducción del libro se incluye un supuesto muy sugerente que aconteció hace casi una década. En 2011, como consecuencia de la crisis inmobiliaria de 2011, los colegios de California de la zona de Twin Rivers estaban pasando una situación económica límite. De hecho, no tenían recursos ni para calefacción. Ahora bien, para paliar esta desesperada situación, les planteó hacer una inyección económica millonaria a cambio de permitir la presencia de publicidad en el interior de los colegios. La publicidad ha llegado a acceder a espacios insólitos. Así, por ejemplo, el consejo escolar de Florida llegó a aprobar incluir en el boletín de calificaciones académicas el logotipo de McDonald's y que quien lograse las mejores notas pudiera tener como premio un Happy Meal.

El autor de la obra Tim WU es profesor de la Universidad de Columbia y colaborador habitual en The New York Times. Resulta especialmente sugerente la descripción de como determinadas pantallas - como el ordenador o los Smartphone- han llegado a invadir espacios privados de nuestras vidas - como, en su momento, lo hizo la radio-. Existen determinados rituales que coadyuvan a que el público en general preste una atención desmedida al correo electrónico, la televisión o Internet — debe destacarse las redes sociales-. Hay dos reglas de la publicidad en la época de Facebook. Por un lado, las marcas manifiestan notable interés en vincularse con determinadas causas sociales como el medio ambiente o la justicia racial. En segundo lugar, que es menos positivo, existe una tendencia a trazar perfiles para el envío de mensajes a los destinatarios

Asimismo, se alude a la reacción que se protagonizó frente a la situación de vacío legal en materia publicitaria. Wu relata como hicieron los ciudadanos de París cuando tomaron conciencia de que las paredes de su ciudad estaban repletas de 
carteles. Así, nació la primera normativa - hoy vigente- que restringe los carteles en espacios públicos. Ahora bien, en el ámbito norteamericano, también se adoptaron medidas como la creación de la Administración de Alimentos y Medicamentos que originariamente se creó, a principios del siglo $\mathrm{XX}$, para luchar contra los productos milagro.

La humanidad, dice $\mathrm{Wu}$, ha tomado conciencia de cuando las cosas han ido demasiado lejos para poder reaccionar. Hay una parte cada vez más numerosa de personas que es consciente de que está pasando demasiado tiempo en las pantallas — televisión, teléfono móvil y ordenador personal- Cuando tomen conciencia de su verdadera relevancia, se organizarán y reaccionarán. De hecho, establece un símil. A su juicio, al igual que en los años cincuenta del siglo pasado, la gente está enganchada como aconteció con el tabaquismo.

La obra que se analiza reflexiona sobre la atención, centrándose en dónde se fija, pero también en el cómo y en el por qué - motivos-. Considera que si siempre estás buscando la manera de entretenerte, puede afirmarse que se es un esclavo del entretenimiento. Como dice $\mathrm{Wu}$, para lograr una mayor atención que las restantes entidades que operan en el mercado debe ofrecerse algo más convincente que la competencia y posicionarse en algún espacio de la vida que no estuviera tan concurrido — es decir, que estuviera más apartado o en barbecho-.

Una de las cuestiones que también se examinan reside en la protección de datos. En este sentido, estudia las diferencias que se suscitan en esta materia entre Estados Unidos y Europa. Así, en el caso del primero, el autor señala que «el presidente Trump evita los canales normales, cuenta mentiras todos los días al público y a sus seguidores», pero en tal país no se ha hecho nada con la vigilancia que, de alguna manera, constituye un instrumento que incrementa la efectividad del secuestro de atención. Por lo que se refiere a la legislación europea - que, en la actualidad, se incluye en el Reglamento Europeo de Protección de Datos- nació ya obsoleta. En efecto, la misma se centraba en cómo se empleaban los datos, pero obviaba la recolección.

El autor — que es un reconocido experto de la tecnología y de la comunicación- no se posiciona, en modo alguno, en contra de los avances tecnológicos. Sin embargo, sí que destaca el uso irregular que de algunas tecnologías se están realizando. Tal uso comenzó desde tiempos pretéritos, en concreto hace más de un siglo cuando los periódicos norteamericanos originarios — de precio elevado para la época, solo al alcance de los más pudientes, sin publicidad y de reducida extensión- dieron paso a otra tipología de periódicos — mucho más económicos y que, por tanto, buscaban llegar a un público generalista, con abundantes anuncios comerciales y de gran extensión-. Los diversos sistemas que buscan captar nuestra atención se han sofisticado cada vez más, dando lugar a: aplicaciones digitales; redes sociales; y determinadas pantallas que han sido diseñadas en virtud de logaritmos con el 
objetivo de lograr persuadir a sus destinatarios. Aunque la Red de redes, en sus orígenes, daba la falsa impresión de ser mejor y diferente, en realidad, deja a la televisión, si se compara, como un instrumento comedido.

El modelo de negocio en el que se apoyan los comerciantes de atención no ha cambiado de forma sustancial. En efecto, impera un desvío gratuito a cambio de un instante que llame nuestra atención que se vende al anunciante que haga la oferta más elevada. Todo ello es visible en múltiples paradigmas que podemos esbozar: de los comienzos de la publicidad a la Web móvil; del correo electrónico a las posiciones de dominio de Google o Facebook; desde el popular reportero norteamericano Ed Sullivan hasta otros personajes tan populares como Trump.

En definitiva, la obra que hemos reseñado aborda, de manera sugerente, toda la problemática que se plantea en torno a la atención. La mayoría de la población no es capaz de dar una vuelta a la manzana sin mirar un momento su smartphone. Cada día recibimos un elenco desmedido de mensajes comerciales que nos distraen, de forma permanente, impidiendo la concentración. Podríamos, a este respecto, plantearnos si existe algún espacio - ya sea público o privado- al que realmente no haya llegado la publicidad. 